\title{
Delineating investment opportunities for stakeholders in sorghum seed systems: a logit model perspective
}

\author{
Judith Ndossi ${ }^{1,2}$, Essegbemon Akpo ${ }^{1,3^{*}}$, Chris O. Ojiewo ${ }^{1}$, Justin Ringo ${ }^{2}$, Eliud Kongola², Ronnie Vernooy ${ }^{4}$, \\ Geoffrey Muricho', Gerald Alex Lukurugu ${ }^{2}$, Lameck Nyaligwa Makoye², Ramadjita Tabo ${ }^{1}$ and Rajeev Varshney ${ }^{1}$
}

\begin{abstract}
Background: Seed systems are considered as a vehicle through which the sustainable agricultural intensification can be achieved. However, most sub-Saharan African countries have been ineffective to provide sufficient incentives for stakeholders to consistently invest in the seed systems specifically for crops like sorghum. This study was therefore conducted to uncover investment opportunities for stakeholders in the sorghum seed systems to attain an impactoriented seed production and delivery systems.
\end{abstract}

Results: The study applied descriptive statistics, Logit regression model, and Gross margin to analyze possible areas for investments. Descriptive statistics analyzed the percentage of farmers using sorghum improved varieties and sources used to obtained improved variety seeds. Logit regression model was applied to analyze factors correlating with planting of improved seeds. Gross margin was applied to show profitability of growing improved sorghum seeds and grain. Findings revealed that $39.2 \%$ of the sampled farmers were growing improved sorghum variety seeds. Farmers obtained improved variety seeds from both informal (57.8\%) and formal (42.2\%) sources. Logit estimates indicate that variety preference, unavailability of seeds, resistance to diseases, and drought had significant correlation with planting of improved variety seeds. Seed companies and quality declared seed (QDS) producers earned high margin of 53,08,900 Tanzanian Shillings per hectare (TZS/ha, 1 USD = 2315 TZS during the period of data collection) and 33,94,709 TZS/ha, respectively. Farmers using improved variety seed earned higher margin $(8,19,805 \mathrm{TZS} / \mathrm{ha})$ than farmers who did not use improved variety seeds (3,17,373 TZS/ha)

Conclusions: The identified investment opportunities were increasing number of farmers using improved variety seeds that would drive increased production, distribution, and marketing of quality seed. The large number of farmers still sourcing seed from the informal channel provides avenue to reach out to these farmers through demand creation and wide variety popularization meeting farmer preferences. The huge margin seed producers make provides good incentive to drive private seed companies and individual seed entrepreneurs to make sustainable business out of sorghum seed. The policy implications for reviving sorghum production and productivity are further discussed.

Keywords: Sorghum, Informal and formal seed systems, Seed business, Smallholder farmers, Tanzania

*Correspondence: akpo.essegbemon@gmail.com; E.Akpo@cgiar.org ${ }^{1}$ International Crops Research Institute for the Semi-Arid Tropics, Patancheru 502 324, Telangana, India

Full list of author information is available at the end of the article

\section{Background}

Agriculture is the backbone for the development of many countries in sub-Saharan Africa (SSA) contributing to about $70 \%$ of employment, $33 \%$ of the gross domestic product (GDP), and 40\% of export earnings [1]. Moreover, agriculture contributes to food security by making 
more food available to households [2]. Food security exists when all people, at all times have physical, socio, and economic access to sufficient, safe, and nutritious food that meets their dietary needs and food preferences for an active and healthy life [3]. For decades' food and nutrition security and poverty reduction have been among the top areas of interventions in SSA countries through various public policies and investments for agricultural development. Yet, tackling these issues in the developing countries continues to be a major challenge [4]. In most SSA countries, agricultural productivity challenges are still persistent, and the region has the lowest productivity in the world [5]. As a result, food insecurity and extreme poverty are still rampart, especially in rural areas. In addition, the challenges of rapidly increasing population, natural resource depletion, increased negative impacts of climate change further exacerbate the problems. The aforementioned factors are therefore compelling for an increased sustainable agriculture productivity [6]. Increased agricultural productivity can improve the welfare of households by enhancing their income and food security [7]. In that regard, sustainable agricultural intensification measures to raise yields and production in the currently available arable land without destroying the environment become a requisite. This is also one of the requirements for attaining the Malabo Declaration goal of eradicating hunger, halving poverty in Africa by 2025, as well as achieving the sustainable development goals by 2030, which particularly aims to achieve food security, improve nutrition, and promote sustainable agriculture [8].

Seed systems are considered as a vehicle through which the sustainable agricultural intensification can be achieved. By seed systems, we understand the different ways farmers can access seeds including the different actors involved in the seed value chain [9]. The seed sector plays an important role in combating food insecurity by availing quality seeds to farmers. Seed is the single most important input for agricultural systems [10]. It possesses a unique feature of being both an agricultural input and output at different periods to different users. Seed is a key determinant of agricultural productivity as it determines both the quantity and quality of the outputs [11]. It is a vehicle for delivering a range of advances such as promoting productivity, nutrition, and resilience, all of which benefit smallholder farmers [12]. In every country, the seed systems are composed of different components, broadly categorized into two and known as formal and informal seed systems [13]. The formal seed system is made up of strict quality-controlled seed. It is usually governed by strict policies and regulations. It is market-oriented and managed by public and private sectors [14]. The informal seed system is a farmer- and community-based, local or traditional seed sector. Activities in the informal seed system are mostly decentralized and depend on the farmers' knowledge [12]. It includes continuous use of home-saved seed [15]. It does not conform to any rule prescribed in the seed regulations at national, regional, and international levels [16].

Between the formal and informal seed systems, there is an intermediate system that integrates the formal and informal systems [17]. The intermediate seed system also called semi-formal seed system aims at empowering registered farmer groups to produce seeds from known source and make them accessible to their peer farmers [18]. These farmer groups are registered either at village or ward level by the local authority, programs or projects. Intermediate seed system looks for opportunities and options to improve both formal and informal systems by recognizing and supporting integration through combining methods from both systems [19]. The three principal components of the intermediate system include cultivars developed and used, seed produced, and stored by famers under local conditions and seed exchange mechanism [20]. Research and development organizations are the pioneers of the intermediate systems as a strategy to fast track quality seed supply to smallholder farmers.

Investments to improve the delivery of seed systems have long been an important component of agricultural development strategies. This can yield high returns in terms of seed production security, food and nutritional security, agricultural productivity, as well as poverty reduction [21]. Diverse and often opposing philosophies shapes seed sector development and much depends on what actors see as the entry point [12]. Levels of investment in many national seed systems tend to be low, varieties produced are not being multiplied, and if they are multiplied, then they do not reach most of the small-scale farmers [22]. However, over the years, gaps within the seed systems have led to different types of interventions, supported by various narratives that foresee different pathways into the future, and it has attracted substantial investments. For instance, from 2007 to 2012, the World Bank has funded 87 seed sector projects worth \$US 513 million with strong focus on marginal crops such as sorghum [12]. Although these projects vary in shape and scale, the majority strive to make quality seeds and traits more available and accessible to farmers. There is however still a notion that despite the tremendous investments, the outcomes are yet to meet expectations and interest of farmers are left unattended [23].

This justifies the need for further research to delineate investment opportunities for enhanced and sustainable quality seed production and delivery to marginalized farming communities in the dryland areas. Therefore, 
this study aims at delineating the investment opportunities in seed systems, with a case study on sorghum.

\section{Study context}

In Tanzania, agriculture accounts for $25.8 \%$ of the GDP and provides $80 \%$ of the total employment [24]. Like most SSA countries, Tanzanian seed industry consists of formal, informal, and intermediate seed systems [25]. With the formal system accounting for around $25 \%$ of required seeds [26], the informal system remains a highly important seed supply source for farmers who continue expanding it [27]. To meet seed demand, Government and development organizations, through public and private seed companies and farmer organizations [28] have been investing in seed delivery systems to facilitate quality seed access. Quality seed which in this study refers to improved variety seed can briefly be defined as seeds that have been produced using formal plant breeding methods with the aim of increasing productivity and production of crops to farmers. Food security and nutrition of people depends on the amount and stability of their farm outputs and income [29] which can be achieved through a good choice of seeds to grow and a strong seed system that supports delivery of quality seeds to farmers.

Development organizations including CGIAR, ASARECA, and AGRA have undertaken many seed system initiatives through various projects and programs to ensure reliable supply of affordable quality seeds to the farmers [30], so that they can increase agricultural productivity, nutrition and rural well-being [31], as well as food security.

Despite these public and private investments and assistance of development organizations, the seed sector is still underdeveloped with mixed performance in most SSA countries [32]. In the context of Tanzania, only a few crops such as maize and rice have a much-advanced seed production and delivery systems as compared to dryland crops like sorghum [33]. Insufficient policy initiatives, including poor public investments to support sorghum seed systems, undermine the reliable availability of quality sorghum seeds. It is still unclear whether the current sorghum seed system will generate enough motivations for the private sector to deliver quality seeds at affordable prices and at scale.

The study aims to define the investment opportunities for stakeholders in the sorghum seed systems. It focuses on the following four research questions (i) to what extent farmers are growing improved variety seeds? (ii) What are the source farmers use to obtain improved varieties? (iii) What are the main factors positively associated with planting of improved variety seeds by farmers? (iv)
Is there profitability of producing certified seed and quality declared seeds (QDS)?

This paper is organized into seven sections. "Background" section provides information on relevant literature related to seed systems, their categorization and functions; also efforts to invest in the existing seed systems are discussed. "Study context" section presents seed systems in Tanzania and initiatives that have been taken to improve it. "Conceptual framework" section discusses different approaches employed to uncover the investment opportunities in the sorghum seed systems. "Data and Methodology" section delivers the methodological approach to achieving the objectives of the study. "Results" section presents the findings and some analyses. "Discussion" section discusses results of the study and place them into the wider context. "Conclusion" section summarizes the paper and presents recommendations arising from this study.

\section{Conceptual framework}

Circumventing investment areas in seed systems to enhance seed production and delivery to farmers can be approached from various angles. In this study, we approach the subject from the perspective of existing gaps in the seed production and delivery systems. According to McGuire [34], gaps in seed system permit a holistic analysis of possible areas for investment. This involves analysis of the number of potential users, understanding seed sources farmers use, understanding factors correlated with farmer choices of improved variety, and profitability of producing seed and grain.

On one hand, the low number of farmers using seed of improved varieties might indicate difficulties in new variety seed uptake. On the other hand, the low number of potential users is concerned with the assumption that there is a large market opportunity to conquer. Supplying seed to those farmers who have not been using improved varieties through collaboration with various stakeholders could then be explored. The sources farmers use to obtain seed of improved varieties provide option to identify the most predominant seed source and subsequent steps needed to boost quality seed demand. The different seed sources that farmers use shows the path that the public and private sectors can leverage on to disseminate improved variety seeds that reach more farmers. The channels farmers use to assess improved variety seeds are important especially in determining the degree and nature of investment within the seed systems [35]. In this study, the formal and intermediate seed systems are put together and termed as formal seed systems, while the informal seed system is taken as stand-alone system.

The factors with positive correlation with improved variety seed planting by farmers indicate the areas to 
work on by various stakeholders. Understanding these factors and how they influence the use of improved variety seeds is important to develop strategies to sustain sorghum variety seed delivery. Farmer's decision to whether and how to use improved variety seeds are conditioned by a number of factors and circumstances [36]. Logit model can be used to analyze underlining factors of farmer's decision to use improved seeds. Several studies (e.g., [29], [37], [38]) have used logit model to analyze different factors influencing farmers' choice to use seed of improved varieties.

The profitability of producing certified and QDS seeds and grain also provides investment incentive for seed producers and farmers. Profit is a main indicator of viability of an enterprise, and ideally, it can be measured using gross margin. This is supported by Mvungi et al. [39] that gross margin is used as a measure of enterprise profitability. Moreover, Fani et al. [40] asserted that gross margin has been used for many years in various literatures to analyze the profitability of farm production practices. Gross margin is the difference between total revenue and total variable cost associated with the enterprise [41]. In that regard, for this study, gross margin can be used to measure profitability of sorghum seed producers and farmers, since it analyzes the performance of an enterprise. Good margin would be an incentive to seed companies to invest in sorghum seed production and farmers to look for quality seed.

\section{Data and methodology}

The study was conducted in nine districts of which seven had undergone seed system interventions through project activities to facilitate seed access to communities. The project "harnessing opportunities for productivity enhancement (HOPE)" was implemented in the intervention areas between 2009-2020. The project facilitated seed production and delivery to farmers using public and private partnerships and community seed production scheme. These districts were Mkalama, Singida DC, Iramba, Ikungi, Serengeti, Rombo, and Momba, whereas the districts that had no intervention were Kongwa and Tarime.

Cross-sectional research design was employed, and data were collected across the surveyed districts. To obtain detailed information, household survey was conducted as well as key informant interviews, with the household survey conducted using semi-structured interviews. To gather information from the respondents, face to face interviews were employed per person using a questionnaire. The sample frame was composed of farmers and seed producers. Some of the information collected from the households included type of varieties used by farmers, sources farmers use to obtain improved seeds, socio-economic characteristics, and cost of grain production. Seed producers' information included cost of seed production, price of seed sold $/ \mathrm{kg}$, and amount of sorghum seed sold.

Two types of sampling were used namely purposive sampling and simple random sampling. The purposive sampling was used to select nine main sorghum growing districts and the main sorghum growing villages per selected district. The simple random sampling was used to select 212 farmers and five seed producers.

Data were analyzed in Stata version 13 software using descriptive statistics, gross margin, and logit regression model. Descriptive statistics included percentage of growers of improved variety seeds vs. non-growers and sources used by farmers to obtain improved variety seeds. Gross margin was used to evaluate the profitability for seed enterprise and farmers but also one of the ways to identify investment opportunities in sorghum seed systems. Values computed for gross margin of seed production and grain production are individual data obtained from the interviews on a hectare basis.

It was computed by

$$
G M=Q_{y} P_{y}-\sum X_{i} P_{x_{i}},
$$

where $\mathrm{GM}=$ Gross Margin; $Q_{y}=$ Total output of crop $(\mathrm{kg}) ; P_{y}=$ Unit of price of output (TZS); $X_{i}=$ Quantity of the input used $(\mathrm{kg}) ; P_{x_{i}}=$ Price per unit of the input (TZS); $Q_{y} P_{y}=$ Total revenue associated with the output (TZS); $\sum X_{i} P_{x_{i}}=$ Summation (overall inputs to give the Total Variable Costs).

Thus

$\mathrm{GM}=$ Gross total revenue - Total variable costs. Here, $\mathrm{GM}=$ Gross Margin (TZS/ha); GTR = Gross total revenue (TZS/ha); TVC $=$ Total variable costs (TZS/ha).

Logit regression model was used to identify factors positively correlated with planting of improved variety seeds by sorghum farmers. The model was fit to estimate the relationship to planting of improved variety seeds, since it analyzes the association between a categorical dependent variable and a set of independent variables [42]. In this study, the dependent variable is the use or not of seed of improved sorghum varieties by farmers, taking the values of 1 or 0 . The value 1 indicates farmers who planted improved sorghum seeds and value 0 indicates farmers who did not. The independent variables linked to the binary dependent variables were variety preference, group membership, availability of improved variety seeds, seed price, resistance to drought, resistance to disease, farm size, and education level.

Past studies have suggested that farmer's decision to plant improved variety seeds is associated with different factors such as socio-economic, institutional, production 
characteristics, and preference. Socio-economic factors like education, whereby education level is associated with the ability to acquire and use improved seeds [43]. Hence, farmers who are educated may use improved seeds than farmers with no education. Farm size is a key indicator of the capacity to earn agriculture income [44], and often, it represents wealth status of the family. Therefore, farmers with large farm size may have more proceeds to purchase improved seeds than farmers with small farm size. Group membership of a farmer may increase access to information on improved seeds [45]. Thus, membership of a farmer's group may increase the likelihood of planting improved seeds. Variety preference has been incorporated in the model, because it captures the effect of farmer's variety preference which may affect farmers' choice of variety for planting. Availability of seed enhances the farmers' decision to plant improved seeds [44]. Availability of improved seeds ensures food security and prosperity of the farmer. Thus, when improved seeds are available to the farmers at the right time, then it may improve farmers' access to seed and ultimately influence the farmers to plant improved seeds. Production characteristics like resistance to drought and resistance to disease are important for explaining choice of planting improved seeds [46, 47]. This is because varieties that can resist drought and disease have more potential of producing more yield than variety without these characteristics, therefore increasing the likelihood of farmers to plant improved seeds. Seed price is a valuable factor in shaping farmer's choice to plant improved seeds [48]. Although improved seeds might give high yield, but if it is not affordable, then it can cause farmers to be reluctant to plant it.

The probability $\left(P_{i}\right)$ that a farmer plants improved sorghum seeds is as follows:

$$
Y_{i}=\beta_{0}+\sum_{i=1}^{n} \beta_{i} X_{i},
$$

where $\beta_{0}$ is constant and $Y_{i}$ is equal to one (1) when a choice is made to plant improved seed and zero (0) otherwise; this means: the equation represents a binary choice involving the estimation of the probability of planning improved sorghum seeds $(Y)$ as a function of independent variables $(X)$.

The logit model uses a logistic cumulative distributive function to estimate, $P$ given by

$$
\begin{aligned}
& P=\left(Y=\frac{1}{X}\right)=\frac{\mathrm{e}^{y}}{1+\mathrm{e}^{y}} \\
& P=\left(Y=\frac{0}{X}\right)=1-\frac{\mathrm{e}^{y}}{1+\mathrm{e}^{y}} \\
& Y=\beta_{1} X_{1}+\beta_{2} X_{2}+\cdots+\beta_{k} X=\sum_{i=1}^{k} \beta_{i} X_{i},
\end{aligned}
$$

where $k$ represents number of independent variables to be analyzed.

The model is specified as indicated by Eq. (6):

$$
Y=\operatorname{Ln}\left(\frac{P}{1-P}\right)=\beta_{0}+\beta_{k}+\varepsilon,
$$

where $Y=$ growing of improved variety seeds; $\operatorname{Ln}\left(\frac{P}{1-P}\right)=$ the ratio of probability of planting improved variety seeds $(p)$ to not planting improved variety seeds $(1-p) ; \beta=$ Slope of coefficient; $X_{k}=$ vector of the explanatory variables (variety preference, group membership, seed availability, seed price, resistance to diseases, resistance to

\begin{tabular}{|c|c|c|c|c|}
\hline Variables & Description & Type of variable & Minimum & Maximum \\
\hline Variety preference & $1=$ improved $; 0=$ local & Dummy & & \\
\hline Group membership & $1=$ yes $; 0=$ otherwise & Dummy & & \\
\hline Seed availability & $1=$ yes $; 0=$ otherwise & Dummy & & \\
\hline Seed price & TZS & Continuous & 120 & 5000 \\
\hline Resistance to diseases & $1=$ yes $; 0=$ otherwise & Dummy & & \\
\hline Resistance to drought & $1=$ yes $; 0=$ otherwise & Dummy & & \\
\hline Farm size & $\mathrm{Ha}$ & Continuous & 0.10 & 10.8 \\
\hline Education & $\begin{array}{l}1=\text { if the respondent has a degree from high } \\
\text { school or lower; } 0=\text { otherwise }\end{array}$ & Dummy & & \\
\hline
\end{tabular}
drought, farm size, and education level); $\varepsilon=$ error term.

The model was expanded to include the variables in Table 1.

Table 1 Description of determinants affecting planting of improved sorghum seeds 
Table 2 Distribution of farmers growing improved variety seeds within sampled intervention and non-intervention districts $(n=83)$

\begin{tabular}{lll}
\hline & Districts & $\begin{array}{l}\text { Growers of } \\
\text { improved variety } \\
\text { seeds (\%) }\end{array}$ \\
\hline Intervention & Ikungi & 3.6 \\
& Iramba & 8.4 \\
& Rombo & 10.7 \\
& Mkalama & 12.0 \\
& Momba & 20.7 \\
Non-intervention & Singida DC & 23.0 \\
& Kongwa & 20.4 \\
Total & Tarime & 1.3 \\
\hline
\end{tabular}

\section{Results}

Farmers growing improved variety seeds among intervention districts and non-intervention districts Out of the 212 farmers sampled, 39.2\% were growing improved variety seeds. Table 2 shows that Singida DC in the intervention districts had the highest rate of farmers growing improved variety seeds of about $23 \%$, followed by Momba with 20.7\%. The results also show that within the intervention areas, there were districts that have below $5 \%$ of farmers producing improved varieties. Kongwa, a non-intervention district hosting the largest grain market in Tanzania, showed $20.4 \%$ of growers of improved variety seeds. The lowest percentage (1.3\%) was recorded in Tarime which is a non-intervention district.

\section{Sources used by farmers to obtain seed of improved varieties}

Farmers using improved varieties obtained their seeds from both formal and informal sources. However, it was observed that $57.8 \%$ of the farmers used informal sources to acquire improved variety seeds (own-saved seeds, neighbor), while $42.2 \%$ of them obtained seeds from formal sources (NGOs, QDS producers, Government, agro-dealers).

Specifically, the survey identified six different sources of seed supply used by farmers to access the improved variety seeds (Table 3 ). It was noted that $48.2 \%$ of the farmers obtained seeds from their own stock, indicating that this source was the most important of the six sources. The Government as well as NGOs were also important sources of seed supply to the farmers with $25.3 \%$ and $13.3 \%$, respectively. The use of other sources
Table 3 Sources used by farmers to obtain improved variety seeds $(n=83)$

\begin{tabular}{lc}
\hline Seed sources & Percentage (\%) \\
\hline Informal sources & \\
Recycled by farmers (own-saved seed) & 48.2 \\
Neighbor/relatives & 9.6 \\
Formal sources & \\
Government (extension, research) & 25.3 \\
NGOs & 13.3 \\
QDS farmers & 2.4 \\
Agro-dealers & 1.2 \\
\hline
\end{tabular}

than the ones mentioned above was modest with $9.6 \%$ farmers accessing seeds from neighbors and $2.4 \%$ farmers accessing seed from QDS producers. Seed access through agro-dealers was almost non-existent, representing only $1.2 \%$ of farmer's seed source.

\section{Factors correlated with planting of improved variety seed by farmers}

The results of the Chi-square test were statistically significant at $1 \%$ level, suggesting that the explanatory variables jointly account for planting of improved sorghum seeds. Variety preference, seed availability, diseases resistance, and drought resistance significantly influenced planting of improved sorghum seed. Variety preference had a positive influence on planting of improved variety seeds at $10 \%$ significance level $(p<0.1)$. It is estimated that farmer preference for improved variety leads to the increase of probability of growing the seed by $3.6 \%$ (Table 4 ). Seed availability was also positive and had a significant effect on planting of improved variety seeds $(p<0.01)$. This indicates that an increase in availability of improved variety seed enhances the probability of farmers growing improved seeds by $10.6 \%$ holding other factors constant.

The estimated coefficients of resistance to diseases were positive and significant at $1 \%$ significance level $(p<0.01)$. Implying that ability of the improved variety seed to tolerate diseases increases the probability to grow improved variety seeds by $6.1 \%$. Tolerance to drought was positively correlated with the planting of improved variety seeds and significant at $1 \%$ significance level $(p<0.01)$. The estimates show that the farmer planting of improved variety seeds increases by $7.2 \%$ if the improved variety is drought-tolerant (Table 4). 
Table 4 Factors with positive correlation with planting of improved variety seeds

\begin{tabular}{|c|c|c|c|c|c|c|}
\hline \multirow[t]{2}{*}{ Variables } & \multirow[t]{2}{*}{ Odd ratio } & \multirow[t]{2}{*}{ Standard error } & \multirow[t]{2}{*}{ Sig } & \multirow[t]{2}{*}{$z$} & \multicolumn{2}{|c|}{$95 \%$ Confidence interval } \\
\hline & & & & & Lower limit & Upper limit \\
\hline Variety preference & 3.603249 & 2.401482 & $0.054^{*}$ & 1.92 & 0.9758614 & 13.30456 \\
\hline Group membership & 1.585764 & 0.7553391 & 0.333 & 0.97 & 0.6234333 & 4.033547 \\
\hline Seed availability & 10.59282 & 7.564658 & $0.001^{* * *}$ & 3.30 & 2.613017 & 42.94186 \\
\hline Seed price & 0.9998588 & 0.0002365 & 0.551 & -0.60 & 0.9993954 & 1.000323 \\
\hline Diseases resistance & 6.105233 & 3.968429 & $0.005^{* * *}$ & 2.78 & 1.707723 & 21.82665 \\
\hline Drought resistance & 7.20753 & 4.402005 & $0.001^{* * *}$ & 3.23 & 2.17728 & 23.85935 \\
\hline Farm size & 1.08244 & 0.1816287 & 0.637 & 0.47 & 0.7790692 & 1.503944 \\
\hline Education level & 0.356938 & 0.2596398 & 0.157 & -1.42 & 0.085787 & 1.485129 \\
\hline Constant & 0.1790915 & 0.1278157 & 0.016 & -2.41 & 0.0442162 & 0.7253847 \\
\hline Prob $>c h i^{2}$ & & & $0.0000^{* * *}$ & & & \\
\hline Pseudo $R_{2}$ & & & 0.5368 & & & \\
\hline Log likelihood & & & -65.736921 & & & \\
\hline Number of obs & & & 212 & & & \\
\hline
\end{tabular}

*** Significant at $1 \%$; ${ }^{*}$ significant at $10 \%$

\section{Profitability of certified and QDS seed and grain production as a proxy for investment worth in seed systems}

\section{Gross margin analysis of sorghum seed production by seed companies and QDS producers}

It was important to show the margins that different seed producers obtained from sorghum seed production per ha to understand the viability of the seed business. Seed producers interviewed included seed companies and farmers who produced quality declared seed. The quality declared seed was produced by either individual farmer or a farmer group. Results from the interview show that (Table 5) the expenses on materials and operations incurred by seed producers in the production of sorghum seed. The total variable costs of producing sorghum seed was 59,41,100 TZS for seed companies and 4,85,291 TZS for QDS producers. Among the components of the total variable costs, the expenditure on operational costs accounted for the largest cost item and amounted about $60 \%$ for both seed companies and QDS producers.

For the seed companies, certification costs had the major operational costs accounting for about $15 \%$, while for the QDS producers, weeding and land preparation were the major operational activities that contributed to the cost of sorghum seed production accounting for around $21 \%$ and $13 \%$, respectively (Table 5). Cost of chemicals was highest for seed companies, accounting for about 34\%, while for QDS producers, fertilizer and rented land were the major inputs on which material expenditure was substantial accounting for about $14 \%$ each. Cost of seeds, bags and fertilizer application accounted for smaller share of the variable cost for seed
Table 5 Averages of estimated variable costs (TZS) of seed companies and QDS producers

\begin{tabular}{|c|c|c|}
\hline Items of cost per ha & Certified seeds $(n=2)$ & QDS $(n=3)$ \\
\hline Rented land (ha) & $1,25,000(2.1)$ & $68,750(14.2)$ \\
\hline Seed & $28,750(0.5)$ & - \\
\hline Fertilizer & $2,17,500(3.7)$ & $70,000(14.4)$ \\
\hline $\begin{array}{l}\text { Chemicals (insecticide, } \\
\text { pesticide, storage chemical, } \\
\text { dressing chemical) }\end{array}$ & $20,22,000(34)$ & $40,999(8.4)$ \\
\hline Bags & $30,000(0.5)$ & $13,500(2.9)$ \\
\hline Sub-total & $2,423,250(40.8)$ & $1,93,249(39.8)$ \\
\hline \multicolumn{3}{|l|}{ Operational costs } \\
\hline Land preparation & $1,06,250(1.8)$ & $65,000(12.9)$ \\
\hline Planting & $75,000(1.3)$ & $20,833(4.3)$ \\
\hline Fertilizer application & $31,250(0.5)$ & - \\
\hline Chemicals application & $73,000(1.2)$ & $10,000(0.2)$ \\
\hline Weeding & $1,25,000(2.1)$ & $1,00,000(20.6)$ \\
\hline Ridging & - & $34,375(7.1)$ \\
\hline Security/guarding cost & $1,15,000(1.9)$ & $10,000(2.1)$ \\
\hline Harvesting & $81,250(1.4)$ & $16,667(3.4)$ \\
\hline Threshing and winnowing & $4,87,500(8.2)$ & $30,000(6.2)$ \\
\hline Grading & $4,55,000(7.7)$ & - \\
\hline Bagging & $33,600(0.6)$ & - \\
\hline Transport & $6,75,000(11.4)$ & $16,667(3.4)$ \\
\hline Certification costs & $9,00,000(15.1)$ & - \\
\hline Land levy & $1,80,000(3)$ & - \\
\hline Uploading and off loading & $1,80,000(3)$ & - \\
\hline Sub-total & $3,517,850(59.2)$ & $2,92,041(60.2)$ \\
\hline Total variable cost & $5,941,100$ & $4,85,291$ \\
\hline
\end{tabular}

1 USD $=2315$ TZS during the period of data collection

Figures in parentheses are percentage of items of total variable cost 
Table 6 Gross margin analysis of sorghum seed producer (TZS/ ha)

\begin{tabular}{lcc}
\hline Item (average) & Certified & QDS producers \\
\hline Gross revenue & $11,250,000$ & $38,80,000$ \\
Cost of materials & $24,23,250$ & $1,93,249$ \\
Operational costs & $35,17,850$ & $2,92,042$ \\
Total variable costs & $59,41,100$ & $4,85,291$ \\
Gross margin & $53,08,900$ & $33,94,709$ \\
\hline
\end{tabular}

$1 \mathrm{USD}=2315 \mathrm{TZS}$ during the period of data collection

Table 7 Variable costs for growers $(n=83)$ and non-growers of improved varieties $(n=129)$ (TZS/ha)

\begin{tabular}{lcc}
\hline Average variable costs & Improved variety seeds & Old variety \\
\hline Rented land & $1,95,319.76(36.7)$ & $1,60,852.71(33.9)$ \\
Land preparation & $72,994.71(13.7)$ & $69,336.21(14.6)$ \\
Seed cost & $39,329.94(7.4)$ & $54,504(11.5)$ \\
Fertilizer & $17,718.02(3.3)$ & $5687.98(1.2)$ \\
Weeding & $93,546.51(17.6)$ & $61,937.98(13.07)$ \\
Ridge & $8575.58(1.6)$ & $2228.68(0.5)$ \\
Insecticides & $9898.55(1.86)$ & $2029.07(0.4)$ \\
Other pesticides & $1482.55(0.3)$ & $12,500(2.6)$ \\
Threshing and winnowing & $24,139.53(4.5)$ & $27,074.61(5.7)$ \\
Harvesting cost & $4229.65(0.7)$ & $8412.79(1.7)$ \\
Transport cost & $27,848.84(5.2)$ & $26,346.89(5.5)$ \\
Security & $14,651.16(2.7)$ & $17,461.24(3.6)$ \\
Grading & $6468.02(1.2)$ & $10,218.02(2.2)$ \\
Packaging (bag and & $14,777.88(2.7)$ & $15,294.89(3.2)$ \\
$\quad$ packaging) & & $4,73,885.91$ \\
Total variable costs & $5,30,980.41$ &
\end{tabular}

$1 \mathrm{USD}=2315 \mathrm{TZS}$ during the period of data collection

Figures in parentheses are percentage of items of total variable cost

companies (about 0.5\% each), while for QDS producers, the lowest cost was for chemical application accounting for about $0.2 \%$.
The revenue per hectare of the seed companies and QDS farmers is presented in Table 6. Results from the interviews show that sorghum seed production is highly variable. Both categories of seed producers obtained a positive return. Seed companies producing certified seeds make larger revenue from sorghum seed production than QDS producers.

\section{Gross margin for growers and non-growers of seeds of improved varieties}

Results from the interview show that the total variable cost for growers of improved variety seeds was 5,30,980 $\mathrm{TZS} / \mathrm{ha}$, while for the non-growers, it was 4,73,886 TZS/ ha (Table 7). Among the components of the total variable costs, land rental, weeding labor, and land preparation were high for farmers. For growers of improved variety seeds land rental, weeding labor and land preparation were about $37 \%, 17 \%$, and $14 \%$, respectively, whereas non-growers of improved variety were about $34 \%, 13 \%$, and $15 \%$, respectively. However, planting material added more cost for non-growers of improved variety accounting for about $11.5 \%$, since broadcasting method involves more amount to plant as compared to growers of improved variety seeds. The cost of insecticide accounted for a small share especially for non-growers of improved variety $(0.4 \%)$ of the total variable cost against about $2 \%$ for growers of improved variety seeds.

Table 8 shows that the average gross margin earned by farmer for sorghum production was 5,18,346 TZS/ ha. For farmers growing improved varieties, the average gross margin was significantly higher $(8,19,805$ TZS) than their counterpart producing old varieties $(3,17,373$ TZS) $(p<1 \%)$.

When data are disaggregated by intervention and nonintervention areas (Table 9), the average gross margin was 5,34,517 TZS/ha for farmers in district that underwent project intervention, while for farmers in nonintervention districts, it was 4,51,738 TZS/ha. This shows

Table 8 Gross margin analysis for growers and non-growers of improved variety seeds (TZS/ha)

\begin{tabular}{llcccc}
\hline & Mean gross margin & Standard error & Standard deviation & 95\% Confidence interval \\
\cline { 4 - 5 } & & & & Lower limit & Upper limit \\
\hline Benefits & $5,18,346.1$ & $94,194.6$ & $13,81,165$ & $3,32,677.9$ & $7,04,014.2$ \\
Non-growers & $3,17,373.3$ & $70,892.8$ & $8,05,188.5$ & $1,77,099.6$ & $4,57,647$ \\
Growers & $8,19,805.2$ & $2,06,666.6$ & $19,16,547$ & $-8,08,896.6$ & $12,30,714$ \\
Diff & $-5,02,431$ & $1,89,625.2$ & & $-1,28,649.5$ \\
$\operatorname{Pr}(T<t)$ & 0.0087 & & & \\
$\operatorname{Pr}(|T|>|t|)$ & 0.0043 & & & \\
$\operatorname{Pr}(T>t)$ & 0.9957 & & & \\
$T$ & -2.649 & & & \\
$D f$ & 213 & & & \\
\hline
\end{tabular}


that farmers in the intervention districts were obtaining higher profit than those in non-intervention districts.

\section{Discussion}

Effective seed systems have the potential to increase productivity and production by delivering quality seeds of new varieties to farmers. The development of an impactoriented seed system is a strategic choice which can be done through appropriate handling of investments areas in the seed sector.

\section{Filling the gaps of improved variety seed use by farmers}

Quality seed is vital to raising agricultural production and it is one of the basic inputs needed for breakthrough in crop production. Unfortunately, the results of this study demonstrate that most of the farmers were not growing improved variety seeds. Only about $39 \%$ of farmers planted improved variety seed among sampled farmers. This conquers with Aloyce et al. [49] who observed that improved variety seed planting by most sorghum farmers is low. The low proportion of farmer growing improved varieties indicates that most farmers were not experiencing maximum benefits from sorghum production. The high number of non-growers of improved variety seed constitutes an investment opportunity for seed companies, QDS producers, and farmer organizations involved in seed business. It is believed that an effective way to increase productivity and enhance peoples' livelihood is broad-based use of new farming technologies such as improved quality seeds. Unfortunately, farmer demand for quality seed remains inconsistent in SSA. Seed companies in Southern Africa failed to invest in developing rural retail networks for open pollinated varieties (OPV) seeds because of the uncertainty in seed demand [50]. Similarly, McGuire et al. [12] added that over the years, seed producers have been producing and supplying seeds, but they have been hindered by lack of demand. Nevertheless, if there is still score number of farmers that are still using landraces, it pertains that there is a huge market gap for the improved variety seeds that needs to be filled. There have been efforts by development organizations to fund the research, production, and supply of improved variety seed and awareness creation through projects, but a few areas have been covered [12]. For instance, organizations such as the International Crops Research Institute for the Semi-Arid Tropics (ICRISAT) have been developing and evaluating sorghum varieties targeting the dry lands in collaboration with Tanzania Ministry of Agriculture and other partner organizations [49]. The survey showed that in the intervention areas, there were higher proportions of farmers growing improved variety seeds against the non-intervention districts. This is a clear indication of the milestones that can be achieved through awareness creation activities to increase use of improved varieties. Only about $2 \%$ of total demands of certified seeds of sorghum were made available to the farmers in Tanzania in 2019 [51]. This emphasize that more investment is needed in production, marketing, promotion, and distribution of improved variety seeds to reach the majority of farmers who are not growing improved varieties. ESAFF [14] acknowledges that the lack of awareness negatively impacts the wide use of improved variety seeds. There is a need to accelerate the use of improved variety seeds to enhance the seed systems through synergized interventions from public and private sectors [14]. The private sector also bears responsibilities to increase farmer's awareness to grow the seed market.

\section{Sources used by farmers to acquire improved variety and avenue for growing seed market}

The study shows that farmers used both the informal and formal seed systems to obtain improved variety seeds for planting, with $57.8 \%$ of the farmers obtaining planting material from the informal sources during planting season. Similar findings were reported by Louwaars et al. [19] that most of the improved variety seeds were accessed through the informal seed system. Kusena et al. [52] add that informal seed system supports more than $80 \%$ of farmers in sub-Saharan Africa and feeding more than $70 \%$ of its population. This system is dominated mostly by own-saved seeds and seeds from neighbors. This corroborates the findings by Alemu et al. [53] that most farmers still depend on the use of saved seed or locally purchased seed. Farmers asserted using their own-saved seeds, because it is usually available during planting season compared to other sources of seed [54]. The dominance of the informal seed system shows that it will continue to play a major role in supplying sorghum seeds to farmers for the coming years. NGOs and government officers were facilitating more in seed delivery than agro-dealers and QDS producers. According to ESAFF [14], the coverage from agro-dealers is minimal in rural areas resulting in limited use of agri-inputs. Agro-dealers have a major role in seed supply systems. For proximity seed supply, agro-dealers network needs to be expanded through close collaboration with public and private seed companies. In the same vain, win-win linkages between QDS producers and seed companies will introduce more farmers to improved varieties and significantly increase the seed market. Croft et al. [55] noted that formal systems contribute very little amount of seeds accessed by farmers, even though they are responsible for developing new improved varieties. The gap in formal seed system opens up an opportunity for investors both in public and private sectors to develop strategic business partnerships 
to make seed available and accessible to smallholder farmers. This would meet the criteria of strong seed systems as reported by Etten et al. [21] who posited that a strong seed system relies on the interconnected performance of three key functions namely seed production and distribution, innovation, and regulations.

The observation showing farmers purchasing a modest part of their seed from various sources implies that farmers would be willing to buy seeds. Similar results were observed in the study conducted on seed systems smallholder farmers use [12]. Farmers are usually reluctant to invest in quality seeds [56]. Thus, the presence of farmers purchasing improved variety seeds shows that farmers are already making such investments and this presents an opportunity to define strategies to improve seed supply to farmers. Understanding the commercial behavior of farmers concerning seed in terms of purchasing practices or use of own-saved seeds helps to gauge the seed market and target promotion to create demand and ensure supply [53]. The integration of both formal and informal seed systems is a major avenue to enhance effectiveness and expansion of seed market. This integration strengthens breeder-led and farmer-led linkages [57]. Through this, more farmers who are experienced with proper technical support and capacity building can invest in producing and diffusing enough quantity and quality improved variety seeds to other peer farmers.

\section{Opening seed market though factors correlated with farmers' planting of improved variety}

It is vital to know the underlying factors that correlate positively with planting of improved variety seeds by farmers. Finding solutions to such factors may in turn improve the use of seeds and ultimately improve sorghum seed system.

The results indicated that variety preference, availability of seeds, resistance to diseases, and drought as the most significant factors motivating farmers to grow improved variety. Similar findings were reported by Timu et al. [58] and Tambo et al. [59]. These factors are perceived to improve crop yield. Akwango et al. [60] asserted that poor harvest threatens food security and livelihoods of household who depends on agriculture for food and income. Moreover, the above-mentioned significant factors are also perceived to develop resource use efficiency, and show consumer preference and acceptability in grain market $[58,61,62]$. The aforementioned factors indicate opportunity for investment to all stakeholders such as research institutes, seed companies, NGOs, and international institutions to develop the improved variety that meet the consumer expectations. Furthermore, the findings show that farmers' preference for variety traits affects their choice, implying that if the variety that does not have the desired traits is produced and supplied, then very few farmers will be attracted to purchase. Improved assessment of farmers' desire and preference contributes to improved seed system interventions [63]. In the light of this, Fadillah et al. [48] opined that the knowledge of ecological, genetic diversity, and traditional varieties in the crops provides much needed resource to build priority breeding programs for varieties preferred by farmers and markets. This implies that through understanding different factors hindering the use of improved variety seed, there is an opportunity for public and private sectors to invest in advanced research, breeding, and development of varieties that meet the market demand. Once seed enters the market, it should be considered part of the farmers' asset to nurture and grow, with support from public and private sector institutions as well as expertise to maintain and improve those varieties [64]. It is crucial that more scientific technologies are developed such as mutation genes of sorghum varieties for improved resistance to biotic and abiotic stresses as well as informing the production environment of farmers [65].

\section{Profitability of producing certified seed, QDS, and grain of improved variety as investment incentive}

The results showed a positive gross margin for both seed companies and QDS producers. The difference in the margins obtained was mostly due to the price difference between the seed company and QDS producers with the QDS farmers gaining lower margin than the seed companies. Similar findings were reported by Katungi et al. [66] on common bean, Akpo et al. [67] on groundnut. Moreover, QDS producers did not bear certification fee and are able to sell their seeds at a lower price. Pal et al. [5] reported that certification costs were additional cost that increased seed production cost. Even though QDS is availed at affordable prices, it only sells within their local areas (ward) [68]. As a result, farmers outside these areas could not access seed; thus, they either access seed through researchers or extension officers. The potential of QDS lies in the ability to produce and supply quality seeds addressing the issue of affordability and proximity availability. This is supported by Coomes et al. [31] that farmer's seed and networks can be advantageous in terms of crop choice, accessibility, and cost. The potential to invest in seed systems lies in the positive gross margin obtained by seed companies and QDS producers. Private companies are profit motivated and usually deal in only small volumes for the less profitable crops [50]. Therefore, only profitable crops and varieties will drive investments in the seed systems. Thus, this becomes a motivation for private seed companies and QDS producers to sustainably invest in sorghum seed business. 
Table 9 Comparative analysis of gross margin earned by farmers in intervention and non-intervention districts (TZS/ha)

\begin{tabular}{llllllll}
\hline $\begin{array}{l}\text { Intervention vs. } \text { non- } \\
\text { intervention districts }\end{array}$ & $\begin{array}{l}\text { Mean gross } \\
\text { margin (TZS/ha) }\end{array}$ & Max & Min & Range & SE (mean) & Cv & Skewness \\
\hline Intervention districts & $5,34,516.7$ & $1,37,00,000$ & $-20,40,550$ & $1,57,00,000$ & $1,12,741$ & 2.77 & 5.09 \\
Non-intervention districts & $4,51,738.5$ & $44,07,727$ & $-3,21,167$ & $47,28,894$ & $1,31,507.2$ & 1.88 & 2.90 \\
\hline
\end{tabular}

$1 \mathrm{USD}=2315 \mathrm{TZS}$ during the period of data collection

The gross margin for grain producers showed that using improved variety significantly incurs higher gross margin compared to old varieties. This result is in conformity with the findings of Maroud et al. [69] that farmers who used improved varieties showed higher marginal returns as opposed to those that used local varieties. Seed system also involves farmers [23] and this implies that they are major stakeholders in the seed system to be critically considered. A positive gross margin for farmers growing improved variety becomes an incentive to their peer invest in improved varieties that meet market demand. An increase in seed demand will also encourage seed companies and other player to expand their activities to areas that have not been reached. According to Rohrbach et al. [22], seed enterprise will only thrive in an appropriate environment and the primary characteristic of such environment is the incentive for farmers to purchase seeds. Finally, project interventions showed positive effects on the realized gross margin by farmers. In the districts that underwent project interventions, the farmers made higher margin, indicating that investments through projects by public sector as well as private sector are critical for boosting the use of improved variety seed and enhancing the seed system performance.

\section{Conclusion}

In this study, we used survey data from farmers and seed producers to examine the investment opportunities for various stakeholders in the seed systems. The findings show that only $39.2 \%$ of the surveyed farmers used improved variety seeds, indicating that there is an investment opportunity in producing and supplying quality seeds for farmers who are currently growing old varieties. Researchers, extension agents, seed companies, agro-dealers, as well as NGOs will have a major role to play through awareness creation to enhance farmer knowledge of new varieties and increase demand. Variety demonstrations and field days are good mechanisms to upscale the new and improved varieties. The findings showing that farmers obtained improved variety seeds from both informal and formal seed systems indicate the need to support the farmer to shift from the informal sector through demand creation. There is an opportunity to invest in formal system, whereby seed companies and QDS farmers, agro-dealers can deliver more seeds and expand their business in areas that farmers have not yet accessed seeds. The proper use of informal seed systems through linkage with formal seeds is very important to promote integrated seed supply systems.

Factors such as variety preference, availability of improved variety seeds, resistance to diseases, and drought had significantly correlated with planting of improved variety seeds by farmers. This shows that there is a need to invest in refining varieties that have desirable traits of farmer and consumers in the grain market. This calls for joint and coordinated collaboration between breeders, private sector, and the end-pull. Certified seed and QDS can be produced and availed to farmers' profitability. And this represents an incentive for investment by seed companies, individual seed entrepreneurs, as well as farmer groups or organizations. The higher earning of farmers using improved variety seeds is also an incentive for farmers to invest in the improved variety seeds. From the findings, we can argue that the investment potentials in sorghum seed system are still high and yet to be taped in by various stakeholders so has to develop the seed sector.

\section{Limitations to this study}

This study was conducted in nine districts of sorghum production in Tanzania. Even if few districts were sampled, the coverage of the main sorghum producing areas in the country allowed to capture the relevant information to uncover investment opportunities in sorghum seed systems. The findings are sound for the readily use by a wider audience and stakeholders interested in investing in sorghum seed systems.

\section{Abbreviations}

GDP: Gross domestic product; HOPE: Harnessing opportunities for productivity enhancement of sorghum and millets in sub-Saharan Africa; ICRISAT: International Crops Research Institute for the Semi-Arid Tropics; QDS: Quality declared seed; OPV: Open pollinated variety; SSA: Sub-Saharan Africa; TZS/ha: Tanzanian Shillings per hectare.

\section{Acknowledgements}

The authors express their gratitude to farmers, seed producers, government officials, and staff of development organizations for their collaborations.

\section{Authors' contributions}

Questionnaire preparation, JN, EA, and CO; tool pre-testing, JN, EA, GM, and CO; data collection process, JN, GAL, and EA; data cleaning and analysis, JN, $\mathrm{EA}$, and GAL; draft preparation, JN, EA, and CO; draft review and editing, JN, EA, 
RV, GM, CO, EN, JR, EK, LNM, RT, and RV. All authors read and approved the final manuscript.

\section{Funding}

The authors would like to appreciate the financial support facilitated by ICRISAT as well as good collaboration from TARI-Hombolo and TARI-Naliendele through AVISA and HOPE projects funded by the Bill and Melinda Gates Foundation (OPP1198373 and OPP1129015).

\section{Availability of data and materials}

Data can be availed but under some restrictions.

\section{Declarations}

\section{Ethics approval and consent to participate}

Data were collected and fully analyzed anonymously. Consent to participate was first obtained from each respondent before proceeding for the interview.

\section{Consent for publication}

The authors agree for the article to be published.

\section{Competing interests}

The authors declare that they have no competing interest.

\section{Author details}

${ }^{1}$ International Crops Research Institute for the Semi-Arid Tropics, Patancheru 502 324, Telangana, India. ${ }^{2}$ Tanzania Agricultural Research Institute, P.O. Box 1571, Dodoma, Tanzania. ${ }^{3}$ Ecole de Gestion Et de Production Végétale Et Semencière, Université Nationale D'Agriculture, BP 43, Kétou, Bénin. ${ }^{4}$ Alliance of Bioversity International and CIAT, c/o Wageningen University \& Research, 6708 PB Wageningen, The Netherlands.

Received: 10 September 2020 Accepted: 3 May 2021

Published online: 11 October 2021

\section{References}

1. Business D. Understanding regulations for small and medium-size enterprises. Washington: The World Bank. 2014. http://documents.worldbank. org/curated/en/115171468330898480/Doing-business-2014-understand ing-regulations-for-small-and-medium-size-enterprises. Accessed 30 Dec 2019.

2. Mengistu DD, Degaga DT, Tsehay AS. Analyzing the contribution of crop diversification in improving household food security among wheat dominated rural households in Sinana district, Bale Zone. Ethiopia Agric Food Secur. 2021;10:7. https://doi.org/10.1186/s40066-020-00280-8.

3. FAO. Declaration on world food security. World Food Summit. 13-17 November 1996. http://www.fao.org/3/w3548e/w3548e00.htm. Accessed 26 Mar 2021.

4. Adjimoti G, Kwadzo G. Crop diversification and household food security status: evidence from rural Benin. Agric Food Secur J. 2018. https://doi. org/10.1186/s40066-018-0233-x.

5. Pal G, Radhika C, Bhaskar KU, Ram H, Prasad SR. A study on comparative economics of grain and seed production of groundnut in Karnataka. India J Exp Agric Int. 2016;11:1-9.

6. Mburu S, Koskey G, Kimiti J, Ombori O, Maingi J, Njeru E. Agrobiodiversity conservation enhances food security in subsistene-based farming systems of Eastern Kenya. Agric Food Secur. 2016. https://doi.org/10.1186/ s40066-016-0068-2

7. Mujeyi A, Mudhara M, Mutenje M. The impact of climate smart agriculture on household welfare in smallholder integrated crop-livestock farming systems: evidence from Zimbabwe. Agric Food Secur. 2021;10:4. https:// doi.org/10.1186/s40066-020-00277-3.

8. Mabe FN, Mumuni E, Sulemana N. Does smallholder farmers' awareness of sustainable development goal 2 improve household food security in the Northern Region of Ghana? Agric Food Secur. 2021;10:9. https://doi. org/10.1186/s40066-020-00281-7.
9. Munyi P, De Jonge B. Seed systems support in Kenya: consideration for an integrated seed sector development approach. J Sustain Dev. 2015:8(2):161.

10. Wekundah JM. Why informal seed sector is important in food security. African technology policy studies network. Biotechnology Trust Africa. Special paper series. 2012. No. 43.

11. Kaguongo W, Maingi G, Giencke S. Post-harvest losses in potato value chains in Kenya analysis and recommendations for reduction strategies. Dtsch Ges für Int Zusammenarbeit GmbH. 2014. https://doi.org/10. 13140/2.1.3761.3764.

12. McGuire S, Sperling L. Seed systems smallholder farmers use. Food Secur. 2016. https://doi.org/10.1007/s12571-015-0528-8.

13. Westengen OT, Haug R, Guthiga P, Macharia E. Governing seeds in East Africa in the Face of climate change: assessing political and social outcomes. Front Sustain Food Syst. 2019. https://doi.org/10.3389/fsufs.2019. 000539.

14. ESAFF. Seeds and agriculture research processes in Tanzania: the case of small scale farmers' participation in setting research agenda. A scoping study report. 2013.

15. Wattnem T. Seed laws, certification and standardization: outlawing informal seed systems in the Global South. J Peasant Stud. 2016. https:// doi.org/10.1080/03066150.2015.1130702.

16. Vernooy R. Options for national governments to support farmer seed systems. The cases of Kenya, Tanzania and Uganda. Hivos and Bioversity International. 2016. https://hdl.handle.net/10568/80762. Accessed 30 July 2020.

17. Gauchan D. Seed sector development in Nepal: opportunities and options for improvement. In: Thapa G, Kumar A, Joshi P, editors. Agricultural transformation in Nepal. Singapore: Springer; 2019. https://doi.org/ 10.1007/978-981-32-9648-0_8.

18. Vabi MB, Ojo P, Zidafamor E, Ajeigbe HA, Ubanduma H. Communitybased seed production system (CBSP) in Nigeria: an opening for complementing national supply of quality seeds, policy brief 34. 2018. http://oar. icrisat.org/id/eprint/10902. Accessed 25 June 2020.

19. Louwaars NP, De Boef WS, Edeme J. Integrated seed sector development in Africa: a basis for seed policy and law. J Crop Improv. 2013. https://doi. org/10.1080/15427528.2012.75142.

20. Mula MG, Sameer Kumar CV, Mula RP. Seed system: the key for sustainable pulse agriculture for smallholder farmers in the dryland tropics. In: 23rd PHILARM National Convention, 16-18 April, 2013, Villa Caceres Hotel, Naga City, Camarines Sur, Philippines. 2013.

21. Etten JV, López Noriega I, Fadda C, Thomas E. The contribution of seed systems to crop and tree diversity in sustainable food systems. In: Mainstreaming agro biodiversity in sustainable food systems: scientific foundations for an agro biodiversity index. Italy: Bioversity International; 2017. p. 81-101.

22. DD Rohrbach JW Low R Pitoro A Cucu J Massingue D Boughton G Rafael AM Paulo D Jocene 2001 Investment priorities for the development of Mozambique's seed system. https://doi.org/10.22004/ag.econ.56047.

23. Almekinders CJ, Walsh S, Jacobsen KS, Andrade-Piedra JL, MCEwan MA, de Haan S, Kumar L, Staver C. Why interventions in the seed systems of roots, tubers and bananas crops do not reach their full potential. Food Secur. 2019. https://doi.org/10.1007/s12571-018-0874-4.

24. United Republic of Tanzania (URT). Agricultural sector development strategy-II 2015/2016-2024/2025. 2016.

25. Mabaya E, Mzee F, Temu A, Mugoya, M. Tanzania Brief 2017-the African seed index. 2017. https://tasai.org. Accessed 31 Dec 2019.

26. Bank W. Agribusiness indicators: Tanzania. The World Bank: Washington, DC, USA. 2012. https://hdl.handle.net/10986/26561. Accessed 22 Feb 2020.

27. Sisay DT, Verhees FJ, Van Trijp HC. Seed producer cooperatives in the Ethiopian seed sector and their role in seed supply improvement: a review. J Crop Improv. 2017. https://doi.org/10.1080/15427528.2017.1303800.

28. Alemu D. Farmer-based seed multiplication in the Ethiopian seed system: Approaches, priorities and performance. FAC working paper 36, Brighton. Future Agricultures Consortium. 2011. https://opendocs.ids.ac.uk/opend ocs/handle/20.500.12413/2252. Accessed 30 Oct 2019

29. Hagos H, Ndemo E, Yosuf J. Factors affecting adoption of upland rice in Tselemti district, Northern Ethiopia. Agric Food Secur. 2018;7:59. https:// doi.org/10.1186/s40066-018-0210-4. 
30. Pretty J, Bharucha ZP. Sustainable intensification in agricultural systems. Ann Bot. 2014. https://doi.org/10.1093/aob/mcu205.

31. Coomes OT, McGuire SJ, Garine E, Caillon S, McKey D, Demeulenaere E, Jarvis D, Aistara G, Barnaud A, Clouvel P, Emperaire L. Farmer seed networks make a limited contribution to agriculture? Four Common Misconceptions Food Policy. 2015. https://doi.org/10.1016/j.foodpol.2015.07. 008.

32. Djamen P. Developing the seed industry to increase agricultural productivity in West and Central Africa: key interventions areas and guiding principles. Res Gate. 2016. https://doi.org/10.13140/RG.2.2.25936.81921.

33. ASARECA KIT. Tanzania seed sector assessment: a participatory national seed sector assessment for the development of an integrated seed sector development (ISSD) programmes in Tanzania. April 2014, Entebbe, Uganda. 2014.

34. McGuire S. Analyzing farmers' seed systems: some conceptual components. Targeted Seed Aid Seed Syst Interv. 2001;6:1.

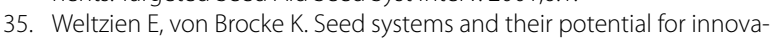
tion: conceptual framework for analysis. Target Seed Aid Strength Small Farmer Seed Syst East Cent Afr. 2001;6:1.

36. M Loevinsohn J Sumberg A Diagne. Under what circumstances and conditions does adoption of technology result in increased agricultural productivity? Protocol. (2012)

37. Wondale L, Molla D, Tilahun D. Logit analysis of factors affecting adoption of improved bread wheat (Triticum aestivum L.) variety: the case of Yilmana Densa district, West Gojam, Ethiopia. J Agric Ext Rural Dev. 2016. https://doi.org/10.5897/jaerd2016.0768.

38. Amare A, Simane B. Determinants of smallholder farmers' decision to adopt adaptation options to climate change and variability in the Muger sub-basin of the Upper Blue Nile basin of Ethiopia. Agric Food Secur. 2017;6:64. https://doi.org/10.1186/s40066-017-0144-2.

39. Mvungi $\mathrm{H}$, Laizer A, Lukumay PJ, Ochieng J, Ngoteya G, Dinssa F, Simon JE, Govindasamy R, Ndinya C, Odendo M. Profitability analysis of traditional african vegetable seeds production in Kenya. J Med Act Plants. 2020;9(4):281-8.

40. Fani R, OdoemenemOben IUNE. Gross margin analysis and constraints faced by small scale rice producers in the west region of Cameroon. J Biol Agric Healthc. 2015;5(21):2224-3208.

41. Leslie DM. Gross margins for selected fruit, vegetable and root crops for the sugar cane belt in Fiji. Suva: Secretariat of the Pacific Community; 2013.

42. Greene WH. Econometric analysis. 6th ed. Upper Saddle River: PrenticeHall; 2008.

43. Mmbando F, Baiyegunhi L. Socio-economic and institutional factors influencing adoption of improved maize varieties in Hai district, Tanzania. J Human Ecol. 2016. https://doi.org/10.1080/09709274.2016.11906955.

44. Makingi G, Urassa JK. Socio-economic factors influencing use of improved technologies by smallholder paddy farmers in Kilombero District, Tanzania. Am J Agric Res. 2017;2:4.

45. Mutanyagwa A, Isinika A, Kaliba A. The factors influencing farmer's choice of improved maize seed varieties in Tanzania. J Sci Res Manag. 2018. https://doi.org/10.18535/ijsrm/v6i4.ah01.

46. Fisher M, Snapp S. Smallholder farmers' perceptions of drought risk and adoption of modern maize in Southern Malawi. Exp Agric. 2014;50:533-48

47. Ullah A, Khan D, Zheng S, Ali U. Factors influencing the adoption of improved cultivars: a case of peach farmers in Pakistan. Ciênc Rural. 2018. https://doi.org/10.1590/0103-8478cr20180342.

48. Fadillah A, Hakim D, Hartoyo S. Factors affecting farmers in adopting VUB rice seeds in Cianjur Regency West Java. 2020. http://ijpsat.ijsht-journals. org. Accessed 28 Dec 2020.

49. Aloyce RK, Mazvimavi K, Ghirmay SG. Economic profitability and risk analyses of improved sorghum varieties in Tanzania. J Dev Agric Econ. 2017. https://doi.org/10.5897/JDAE2017.0833.

50. Setimela PS, Monyo E, Banziger M. Successful community-based seed production strategies. Mexico: CIMMYT; 2004.
51. United Republic of Tanzania (URT). Ministry of Agriculture. 2019. http:// www.kilimo.go.tz. Accessed 3 June 2020.

52. Kusena K, Wynberg R, Mujaju C. Do smallholder farmer-led seed systems have the capacity to supply good-quality, fungal-free sorghum seed? Agric Food Secur. 2017;6:52. https://doi.org/10.1186/s40066-017-0131-7.

53. Alemu D, Rashid S, Tripp R. Seed system potential in Ethiopia: constraints and opportunities for enhancing the seed sector. Gates Open Res. 2019. https://doi.org/10.21955/gatesopenres.1115840.1.

54. Walsh S, Baributsa D, Remington T, Sperling L. Seed storage brief\# 2: Hermetic seed storage technology: principles, use, and economics-a practitioner's guide. Nairobi: Catholic Relief Services; 2014.

55. Croft MM, Marshall Ml, Odendo M, Ndinya C, Ondego NN, Obura P, Hallett SG. Formal and informal seed systems in Kenya: supporting indigenous vegetable seed quality. J Dev Stud. 2018. https://doi.org/10.1080/00220 388.2017.1308487.

56. Almekinders C, Graham T. What to do with the seed for small-scale farmers after all? Questions on seed supply strategies for the formal sector, considering PPB successes. Cultivos Tropicales. 2003;24(4):5-8.

57. Almekinders CJ, Thiele G, Danial DL. Can cultivars from participatory plant breeding improve seed provision to small-scale farmers? Euphytica. 2007;153(3):363-72

58. Timu AG, Mulwa R, Okello J, Kamau M. The role of varietal attributes on adoption of improved seed varieties: the case of sorghum in Kenya. Agric Food Secur. 2014. https://doi.org/10.1186/2048-7010-3-9.

59. Tambo JA, Abdoulaye T. Climate change and agricultural technology adoption: the case of drought tolerant maize in rural Nigeria. Mitig Adapt Strateg Glob Chang. 2012;17(3):277-92.

60. Akwango D, Obaa B, Turyahabwe N, Baguma Y, Egeru A. Effect of drought early warning system on household food security in Karamoja sub region, Uganda. Agric Food Secur. 2017. https://doi.org/10.1186/ s40066-017-0120-x.

61. Ghimire R, Wen-Chi HU, Shrestha RB. Factors affecting adoption of improved rice varieties among rural farm households in Central Nepal. Rice Sci. 2015;22(1):35-43.

62. Lunduka R, Fisher M, Snapp S. Could farmer interest in a diversity of seed attributes explain adoption plateaus for modern maize varieties in Malawi? Food Policy. 2012. https://doi.org/10.1016/j.foodpol.2012.05.001.

63. Spielman D, Mekonnen D. Seed demand and supply responses. Ethiopia: IFPRI; 2018. p. 71-96.

64. Greenberg S, Jones G. Nuanced rhetoric and the path to poverty: AGRA, small-scale farmers, and seed and soil fertility in Tanzania; the African Centre for Biosafety: Johannesburg, South Africa. 2015. https://www. researchgate.net. Accessed 1 May 2020.

65. Rojas-Vásquez R, Gatica-Arias A. Use of genome editing technologies for genetic improvement of crops of tropical origin. Plant Cell Tiss Organ Cult. 2020. https://doi.org/10.1007/s11240-019-01707-2.

66. Katungi E, Wozemba D, Rubyogo JC. A cost benefit analysis of farmer based seed production for common bean in Kenya. Afr Crop Sci J. 2011:19(4):409-15.

67. Akpo E, Muricho G, Lukurugu GA, Opie H, Ojiewo CO, Varshney R. Legume seed production for sustainable seed supply and crop productivity: case of groundnut in Tanzania and Uganda. J Crop Improv. 2020. https://doi. org/10.1080/15427528.2020.1740368.

68. United Republic of Tanzania. The seed act no. (1), 18. 2003. https://www. kilimo.go.tz. Accessed 15 April 2020.

69. Maruod E, Breima E, Elkhidir E, El Naim A. Impact of improved variety seeds on small farmers productivity, income and livelihood in Umm Ruwaba locality of North Kordofan, Sudan. Int J Agric For. 2013. https:// doi.org/10.5923/j.ijaf.20130306.01.

\section{Publisher's Note}

Springer Nature remains neutral with regard to jurisdictional claims in published maps and institutional affiliations. 